\title{
Evaluation of the Effectiveness of Different Acid Digestion on Sediments
}

\author{
Fabunmi Idera $^{1 *}$, Olumodeji Omotola ${ }^{2}$, Uyimadu John Paul ${ }^{3}$, Adeleye Adedayo ${ }^{4}$ \\ ${ }^{I}$ Department of Physical and Chemical Oceanography, Nigerian Institute for Oceanography and Marine \\ Research; Nigeria. \\ ${ }^{2}$ Department of Physical and Chemical Oceanography, Nigerian Institute for Oceanography and Marine \\ Research; Nigeria. \\ ${ }^{3}$ Department of Physical and Chemical Oceanography, Nigerian Institute for Oceanography and Marine \\ Research; Nigeria. \\ ${ }^{4}$ Department of Physical and Chemical Oceanography, Nigerian Institute for Oceanography and Marine \\ Research; Nigeria.
}

\begin{abstract}
The efficiency of four different acids mixtures were evaluated in the determination of total concentration of $\mathrm{Pb}, \mathrm{Zn}, \mathrm{Cu}, \mathrm{Cd}, \mathrm{Cr}$ and $\mathrm{Fe}$ in sediments samples. The acids combination employed included nitric- perchloric acid (NP), aqua regia (NH), sulphuric- hydrogen peroxide (SP) and nitric acid. Sediment samples were taken from five different Lagos lagoon locations; mid lagoon $(M L)$, University of Lagos (UL), Oworonsoki $(O W)$, Ikoyi $(I K)$ and Oko-baba $(O B)$. Validation of the method was performed by using certified reference material IAEA-158 from the International Atomic Energy Agency analytical quality control services, Vienna, Austria. Using Principal component Analysis (PCA), the results revealed that SP acid mixture was efficient for the recovery of $\mathrm{Pb}, \mathrm{Cd}$ and $\mathrm{Cr}$ while $\mathrm{NP}$ and $\mathrm{NH}$ gave good results and to some extent nitric acid for the extraction of $\mathrm{Zn}, \mathrm{Fe}$ and $\mathrm{Cu}$; these procedures were recommended for the qualitative determination of $\mathrm{Zn}$, $\mathrm{Cu}$ and $\mathrm{Fe}$ in sediment. When employing the NP method, the perchloric acid should be added at the later stage of digestion to avoid explosion.
\end{abstract}

\section{Introduction}

As a growing global population, there has been need to produce food, water and shelter and this has caused focus on the ocean to help sustain some of our basic needs. The contamination of the seafloor by chemical inputs (pollution) affects and threatens the benthic environment. These pollutants are consumed up by bottom dwelling organisms and transferred up the food chain, adversely affecting organism's activity, growth, metabolism and reproduction [1], killing some organisms in the process and reducing food availability in the ocean. The formation of seawater and seafloor with relation between chemical compounds (inorganics and organics), how chemical inputs (pollution) affects it and how the chemistry of the ocean affects or is affected by biological geographical and physical factors has been of great concern over decades. However, the water body, sediments and aquatic life (bio indicators) have been used as monitors to evaluate the level of pollution in the marine environment [2].

Heavy metals have been a source of pollution to the environment over the last century. This is due to fast growing economy and industrialization. Sources of these pollutants range from residential wastes, industrial effluent/wastes, agricultural tools waste, mechanic village scraps and more recently electronic waste. The receiving systems are soil, underground water, rivers/streams, lagoons and sea, which finally settle down or accumulate in the ocean. Scientists over time have assessed the level of heavy metals in the environment as well as investigated the level at which it could be detrimental to life $[1,3,4,5,6,7,8]$.

Heavy metal quantitative determinations have been done majorly through two different methods; wet digestion and dry ashing followed by acid dissolution [9]. Wet digestion involves destruction of the organic matter and dissolution of heavy metals. Hossner [10] reported that the advantages of the dissolution of heavy metals in sediments and soils using concentrated inorganic acids are low cost and low salt matrix in the final solution for the determination of total heavy metal content. Acids used for wet digestion include nitric acid, sulphuric acid, hydrochloric acid, perchloric acid, hydrogen peroxide [11]. These acids have been used either alone or in ratios. Hydrofluoric acid (HF), hydrochloric acid $(\mathrm{HCl})$, nitric acid $\left(\mathrm{HNO}_{3}\right)$, perchloric acid $\left(\mathrm{HClO}_{4}\right)$, and sulphuric acid $\left(\mathrm{H}_{2} \mathrm{SO}_{4}\right)$ have been used singly and extensively to optimize extraction from the organic matrix $[12,13]$.

Gorsuch [14] discovered that the methods of digestion that involves a mixture of nitric, sulphuric or perchloric acids were satisfactory for digesting mineral elements in organic and biological materials. However, perchloric acid is potentially hazardous during the digestion of biological materials and can cause the loss of potassium and boron [15]. Baker and Amacher [16] recommended use of $\mathrm{HF}-\mathrm{HNO}_{3}-\mathrm{HClO}_{4}-\mathrm{H}_{2} \mathrm{SO}_{4}$ for the total 
analysis of $\mathrm{Cd}, \mathrm{Cu}, \mathrm{Ni}$, and $\mathrm{Zn}$ in soils, but this was modified by Burau [12] by replacing $\mathrm{H}_{2} \mathrm{SO}_{4}$ with $\mathrm{HCl}$. This is because $\mathrm{Pb}$ precipitates with $\mathrm{H}_{2} \mathrm{SO}_{4}$ in solution. The above methods have however been shown not to completely dissolve silicate, but they are sufficiently good to attack and dissolve heavy metals bound to soil. It was reported by Stephen P. et al. [17] that using aqua regia and block digesters, digestion is faster, more economical and can be very simply modified to suit different types of soil. Aqua regia (ratio 3:1 or 4:1 v/v) has been said to extract effectively trace metals in sediments [18]. Sastre et al. [19] stated that nitric acid digestion was an optimum method for estimating heavy metal content in soil samples with high organic matter content, being superior to microwave-assisted and aqua regia digestions.important compost constituents [20]. Heavy metals in the silicate mineral require digestion with hydrofluoric acid (HF) and strong acids. However, the use of $\mathrm{HF}$ in routine laboratories is not recommended, as it is highly corrosive and difficult to handle.

Numerous studies have succeeded in improving methods for proper extraction of chosen elements. The objectives of our study are twofold. First, we aim to evaluate and recommend the most appropriate acids mixture for the dissolution of marine sediments in determination of specific heavy metals content. This has resulted in suggesting simple, rapid, reliable and accurate method for the preparation of large numbers of marine sediment samples. Second, we determine the total concentration of the heavy metals obtained from acid digestion mixtures, to know the level of pollution of Lagos Lagoon. We hence discuss the extent of heavy metal pollution around the highly populated locations of Lagos Lagoon. The overall objective of the study is to evaluate and recommend the most appropriate digestion method for determining $\mathrm{Pb}, \mathrm{Zn}, \mathrm{Cu}, \mathrm{Cd}, \mathrm{Cr}$ and $\mathrm{Fe}$ in sediments from various sites putting into consideration the above advantages.

\subsection{Study Area}

\section{Materials and Methods}

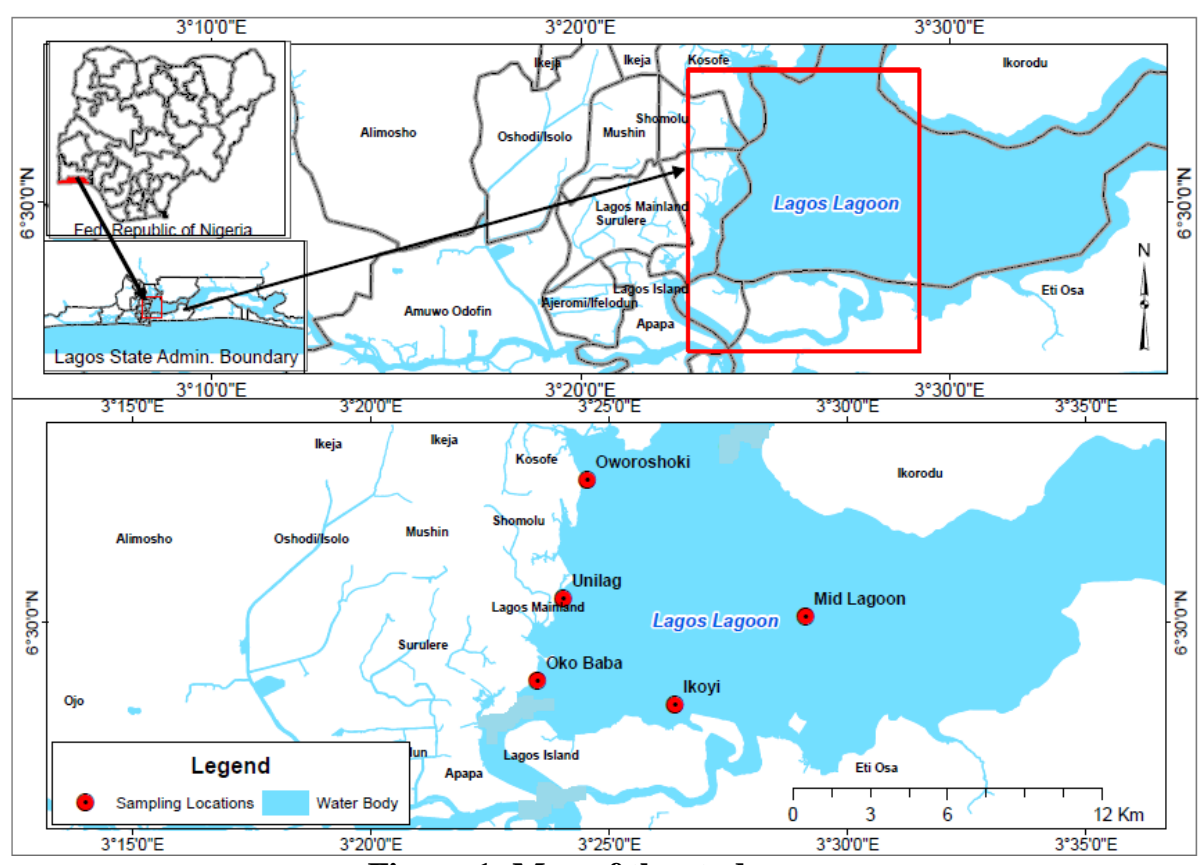

Figure 1: Map of the study area.

Fig. 1 above shows the sampling stations on Lagos Lagoon while Table 1 below recorded the coordinates and approximate depth for each sampling station respectively. Lagos Lagoon has estimated area of $150.56 \mathrm{~km}^{2}$. Lagos Lagoon receives a number of important large rivers, namely: Yewa, Ogun, Osun and Ona [21]. The brackish water lagoon surrounds the Lagos Island and empties at Lagos harbour into the Atlantic Ocean. Lagos is located on the western side of Nigeria and has in size 3,577 sq. km with a maritime shoreline of about $180 \mathrm{~km}$ as its southern border. The Lagos Lagoon is generally shallow in most parts with the exception of some dredged parts (depth $>10 \mathrm{~m}$ ), notably in the Lagos harbour. Lagos Lagoon ecosystem serves as a source of affordable protein in term of sea foods and means of transportation for the local populates living around it. It has been reported that the discharge of urban and industrial wastes into the Lagos Lagoon have resulted in a significant depletion of its coastal terrain and negative impact on the brackish water [22,23].

Sediment samples were taken from five different Lagos lagoon locations; mid lagoon (ML), University of Lagos (UL), Oworonsoki (OW), Ikoyi (IK) and Oko-baba (OB). Sediments were collected via grab sampler, placed in nylon bags and freeze dried. The sediment samples vary from clayey, sandy and loamy textures. The 
sediment samples were decomposed using four different acids and subsequently boiled on a hot plate of about $100^{\circ} \mathrm{C}$.

Table 1: The study stations, their coordinates and approximate depth

\begin{tabular}{|l|l|l|}
\hline LOCATION & COORDINATES & APPROXIMATE DEPTH $(\mathrm{m})$ \\
\hline OWORONSOKI & $\begin{array}{l}\mathrm{N} 06^{\circ} 32.961^{\prime \prime} \\
\text { E } 003^{\circ} 24.532^{\prime \prime}\end{array}$ & 0.40 \\
\hline OKO BABA & $\begin{array}{l}\mathrm{N} 06^{\circ} 28.800^{\prime \prime} \\
\text { E } 003^{\circ} 23.468^{\prime \prime}\end{array}$ & 1.25 \\
\hline UNILAG & $\begin{array}{l}\text { N06 } 30^{\prime} 479^{\prime \prime} \\
\text { E003 } 24^{\prime} 024^{\prime \prime}\end{array}$ & 1.50 \\
\hline MID LAGOON & $\begin{array}{l}\mathrm{N} 06^{\circ} 30.770^{\prime \prime} \\
\text { E } 003^{\circ} 28.212^{\prime \prime}\end{array}$ & 4.20 \\
\hline IKOYI & $\begin{array}{l}\text { N0628.209 } \\
\text { E00323.872 }\end{array}$ & 2.40 \\
\hline
\end{tabular}

\subsection{Reagents}

All reagents and acids used were of high purity and analytical grade supplied by BDH laboratory supplies England.

Stock standard solutions of the elements were obtained from standard inorganic ventures, USA. Serial dilutions were made with de-ionized double-distilled water in order to prepare working solution.

\subsubsection{Nitric acid digestion method $(\mathbf{N})$}

One gram each of sample was placed in a $250 \mathrm{ml}$ conical flask and $10 \mathrm{ml} \mathrm{HNO}_{3}$ was added, the sample was heated for about $45 \mathrm{mins}$. $10 \mathrm{ml}$ of $\mathrm{HNO}_{3}$ was then added and heated at a constant temperature of about $120^{\circ} \mathrm{c}$ until a clear solution was obtained and the volume was reduced by evaporation to about $5 \mathrm{mls}$. The flask was cooled at room temperature and the mixture was filtered through a $0.45-\mu$ Millipore membrane filter paper transferred quantitatively to a $50 \mathrm{ml}$ volumetric flask by adding de-ionized and double-distilled water.

\subsubsection{Aqua-regia digestion method $(\mathrm{NH})$}

This method was partly modified from that of ISO 11466 [24]. $1.0 \mathrm{~g}$ each of sample was treated with $15 \mathrm{ml} \mathrm{HCl}$ and $5 \mathrm{ml} \mathrm{HNO}$ (ratio 3:1). The sample was then heated on a hot plate with the temperature gradually increased until decomposition was complete and volume reduced by evaporation to about $5 \mathrm{ml}$. The samples were filtered, washed with de-ionized and double-distilled water, transferred quantitatively to a $50 \mathrm{ml}$ volumetric flask.

\subsubsection{Sulphuric acid- Hydrogen peroxide digestion method (SP)}

Jones and Case [25]'s approach was adopted. $1 \mathrm{~g}$ each of sediment sample was weighed into a conical flask. $7 \mathrm{ml}$ of concentrated $\mathrm{H}_{2} \mathrm{SO}_{4}$ was added. The mixture was allowed to stand for $45 \mathrm{mins}$ at room temperature. $7 \mathrm{ml}$ of $30 \% \mathrm{H}_{2} \mathrm{O}_{2}$ was added to the sample and heated on a hot plate for about $45 \mathrm{mins}$. The mixture was allowed to cool at room temperature and $2 \mathrm{ml} \mathrm{H}_{2} \mathrm{O}_{2}$ was added and the mixture further heated gradually. The mixture was removed when the solution was clear and volume was about $5 \mathrm{ml}$. Following cooling, the mixture was filtered through a $0.45-\mu$ Millipore membrane filter paper transferred quantitatively to a $50 \mathrm{ml}$ volumetric flask by adding de-ionized and double-distilled water.

\subsubsection{Nitric-perchloric acid digestion method (NP)}

One gram each of sample was weighed into a conical flask and $10 \mathrm{ml}$ concentrated $\mathrm{HNO}_{3}$ was added. The mixture was boiled at a constant temperature for about $45 \mathrm{mins}$. After cooling, $5 \mathrm{ml}$ of $70 \% \mathrm{HClO}_{4}$ was added and the mixture further boiled to release white fumes. After cooling $20 \mathrm{ml}$ distilled water was added and heated until a clear solution was obtained [26]. At room temperature, the mixture was filtered through a $0.45-\mu$ Millipore membrane filter paper transferred quantitatively to a $50 \mathrm{ml}$ volumetric flask by adding de-ionized and double-distilled water.

\subsection{Quality control}

Validation of the method presented in this study was performed by standard reference material from the International Atomic Energy Agency (IAEA-158), analytical quality control services; Vienna, Austria was digested using the four different digestion methods. This was done as a reference for quality control and assurance of the different methods; nitric acid method (SN), aqua regia method (SNH), nitric-perchloric acid method (SNP) and sulphuric acid- hydrogen peroxide method (SSP). 


\subsection{Instrumentation}

An Agilent Atomic Absorption Spectrometer model 240A was used for the determination of all the elements after successive dissolution, decomposition and made up to the 50ml mark in a volumetric flask. Simultaneous background corrections were made using a deuterium lamp.

\section{Results and Discussion}

Fig. 2 shows percentage recoveries of heavy metals in standard reference material IAEA-158 by four digestion methods described above. The standard deviation of replicated standard samples was less than $2 \%$. The concentrations of heavy metals are expressed as milligram/Kilogram $(\mathrm{mg} / \mathrm{Kg})$ of dried sediment. The recoveries of $\mathrm{Pb}, \mathrm{Zn}, \mathrm{Cd}, \mathrm{Cu}, \mathrm{Cr}$ and $\mathrm{Fe}$ ranged from $74-104 \%$ for $\mathrm{Pb}, 88-99 \%$ for $\mathrm{Zn}, 87-123 \%$ for $\mathrm{Cd}, 78-90 \%$ for $\mathrm{Cu}, 95-108 \%$ for $\mathrm{Cr}$ and $65-108 \%$ for $\mathrm{Fe}$. The recovery of $\mathrm{Zn}$ and $\mathrm{Cu}$ were similar as they are said to have similar behaviours in soil [27] with the lowest percentage recovery of 78-99\%. The best recoveries were found in Cd which ranged from $87-123 \%$ for the digestion methods. The measured values were within $1 \%$ of accepted values.

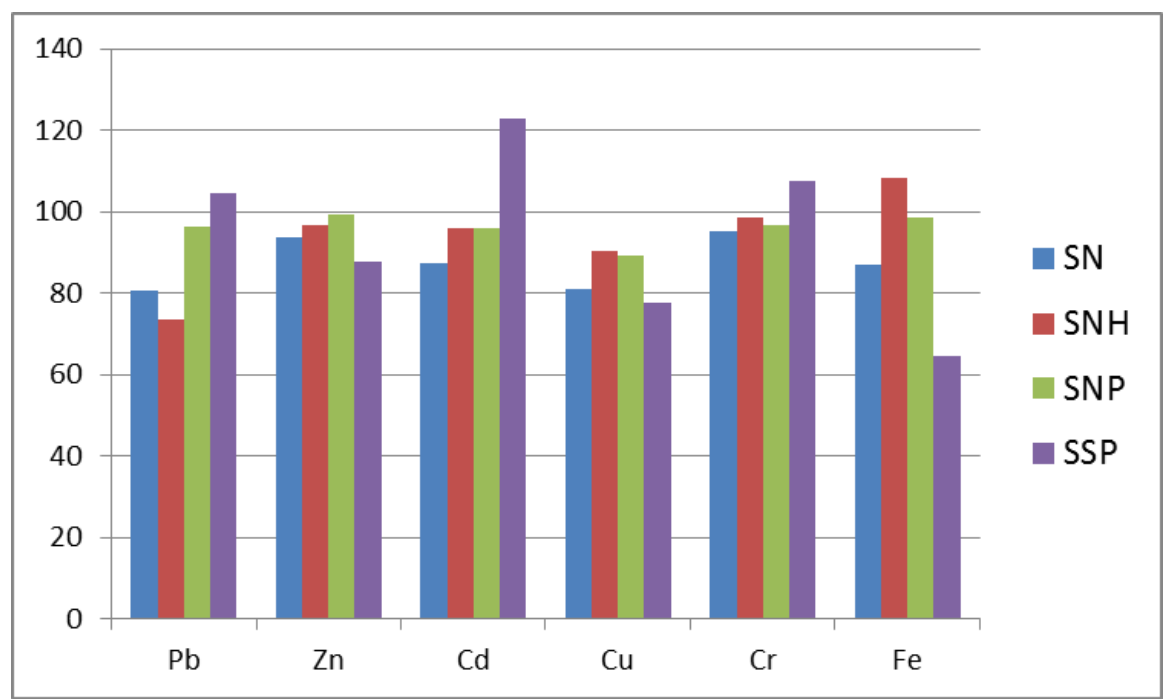

Figure 2: Percentage $(\%)$ recovery analysis of heavy metals content in standard reference material

The mean values and standard deviations of the total content of heavy metals in sediment determined by the different digestion methods are shown in Table 2. The data showed levels of heavy metals in sediment at different points of the Lagos lagoon; Mid-lagoon (ML), Unilag (UL), Oworonsoki (OW), Ikoyi (IK) and OkoBaba (OB).

For $\mathrm{Pb}$, it was observed that the SP acid mixture gave the highest extraction for the entire sampled sites. Although $\mathrm{H}_{2} \mathrm{SO}_{4}$ has been said to reduce the sensitivity of metal detection since it precipitates metals $[12,28,29]$, the reverse was the case for this study. Simpson et al. [30] reported that in anthropogenically metal contaminated sulphide enriched estuarine sediments, $\mathrm{Pb}$ and $\mathrm{Zn}$ contaminants might not occur as metal sulphides but metal powder oxides. Stum and Brauner [31] also explained that in oxygenated seawater, $\mathrm{Pb}$ occurred predominantly as carbonates of inorganic species. The relative affinity of soil for various heavy metals was said to increase in order $\mathrm{Ni}<\mathrm{Zn}<\mathrm{Cd}<\mathrm{Cu}<\mathrm{Cr}<\mathrm{Pb}$ [27]. This emphasises the effectiveness of the strongest oxidizing acid mixture SP used in this study for the extraction of $\mathrm{Pb}$. NP extraction was the next preferred acid mixture, although the values were lower compared to that of SP acid mixture, its values were higher than that of nitric acid and $\mathrm{NH}$. This shows that for effective release of $\mathrm{Pb}$, the use of a strong oxidizing acid mixture must be employed.

In this study, all sediments decomposed with acid mixture sulphuric acid and hydrogen peroxide (SP) gave good extraction of Cd concentration. Earlier investigation supports the efficiency of SP acid mixture in the determination of $\mathrm{Cd}$, which reveals that $\mathrm{Cd}$ bond to acid volatile sulphur can be liberated rapidly as a result of aeration of sediment and elevated oxygen [32,33]. Due to the high oxidizing quality of hydrogen peroxide, Cd is oxidized to soluble $\mathrm{CdSO}_{4}$ during aerobic extraction [34]. Based on this result, aqua regia (NH) predominantly gave a lower extraction in the determination of $\mathrm{Cd}$ followed by nitric acid (N) extraction. Zeng et al. [28], presented similar results in the digestion methods for total heavy metals in sediment and soil, which revealed that the total mean $\mathrm{Cd}$ content of sediments digested by NH method was lower compared to other acid mixture digestion. 
From the plot below (Fig. 3) nitric acid, NH and NP acid mixtures were good for the extraction of $\mathrm{Zn}$. Although all the acid mixtures showed high extraction of $\mathrm{Zn}$ concentration from the sampled sites, however, it cannot be clearly determined the method that best determines Zn. Thalita [35] showed that EPA 3050 and EPA 3051A presented the highest recovery of $\mathrm{Pb}$ and $\mathrm{Zn}$ for most residues. Also Nemati et al. [36] reported that microwave assisted EPA 3015A is most recommended for determination of $\mathrm{Zn}$. Adsorption density of heavy metals is said to increase in order of $\mathrm{Pb}<\mathrm{Cu}<\mathrm{Zn}$ which shows that adsorption behaviour of $\mathrm{Cu}$ and $\mathrm{Zn}$ is very much similar in terms of maximum adsorption capacity [27]. Morillo et al. [37] reported that $\mathrm{Zn}$ metal has the greatest mobility. Large amount of these element are present in the acid soluble fraction.

Table 2: Heavy metal content (mg/kg) in sediment samples by four digestion methods

\begin{tabular}{|l|l|l|l|l|l|l|}
\hline & Pb & Zn & Cd & Cu & Cr & Fe \\
\hline MLN & $14.035 \pm 0.001$ & $104.845 \pm 0.0010$ & $3.55 \pm 0.0004$ & $22.25 \pm 0.0001$ & $7.95 \pm 0.0002$ & $1182.5 \pm 0.0006$ \\
\hline MLNH & $2.86 \pm 0.0001$ & $39.125 \pm 0.0006$ & $2.6 \pm 0.0007$ & $38.75 \pm 0.0001$ & $7.5 \pm 0.0004$ & $1443 \pm 0.0009$ \\
\hline MLNP & $21.87 \pm 0.0004$ & $33.66 \pm 0.0004$ & $4.3 \pm 0.0023$ & $28.5 \pm 0.0001$ & $12.35 \pm 0.0001$ & $1465.5 \pm 0.0004$ \\
\hline MLSP & $67.535 \pm 0.0058$ & $30.38 \pm 0.0009$ & $9.1 \pm 0.0004$ & $10 \pm 0.0001$ & $26.05 \pm 0.0001$ & $2601 \pm 0.0006$ \\
\hline ULN & $32.005 \pm 0.0005$ & $130.07 \pm 0.0014$ & $3.75 \pm 0.0003$ & $17.95 \pm 0.0002$ & $53.35 \pm 0.0001$ & $39010 \pm 0.0030$ \\
\hline ULNH & $30.24 \pm 0.0005$ & $140.935 \pm 0.0007$ & $4.5 \pm 0.0004$ & $19.25 \pm 0.0001$ & $62.4 \pm 0.0004$ & $40458.5 \pm 0.0029$ \\
\hline ULNP & $46.035 \pm 0.0003$ & $148.07 \pm 0.0002$ & $5.55 \pm 0.0007$ & $21.55 \pm 0.0001$ & $68.35 \pm 0.0004$ & $41564 \pm 0.0024$ \\
\hline ULSP & $67.94 \pm 0.0004$ & $70.43 \pm 0.0002$ & $8.45 \pm 0.0004$ & $10.15 \pm 0.0001$ & $59 \pm 0.0002$ & $10091 \pm 0.0006$ \\
\hline OWN & $19.85 \pm 0.0006$ & $63.815 \pm 0.0005$ & $5.65 \pm 0.0005$ & $6.7 \pm 0.0001$ & $34.8 \pm 0.0003$ & $26047 \pm 0.0023$ \\
\hline OWNH & $19.125 \pm 0.0003$ & $113.69 \pm 0.0013$ & $4.55 \pm 0.0004$ & $13.65 \pm 0.0001$ & $48.85 \pm 0.0004$ & $36478 \pm 0.0019$ \\
\hline OWNP & $35.435 \pm 0.0007$ & $110.455 \pm 0.0008$ & $7.05 \pm 0.0002$ & $13.35 \pm 0.0001$ & $57.2 \pm 0.0001$ & $38036 \pm 0.0029$ \\
\hline OWSP & $94.625 \pm 0.0002$ & $75.825 \pm 0.0008$ & $11.3 \pm 0.0006$ & $9.4 \pm 0.0001$ & $96.15 \pm 0.0002$ & $34510.5 \pm 0.0008$ \\
\hline IKN & $14.83 \pm 0.0003$ & $36.135 \pm 0.0003$ & $5.25 \pm 0.0002$ & $2.2 \pm 0.0001$ & $37.4 \pm 0.0001$ & $13997 \pm 0.0016$ \\
\hline IKNH & $6.55 \pm 0.0013$ & $35.635 \pm 0.0003$ & $2.85 \pm 0.0037$ & $2.35 \pm 0.0001$ & $42.5 \pm 0.0001$ & $17091.5 \pm 0.0016$ \\
\hline IKNP & $11.145 \pm 0.0022$ & $25.485 \pm 0.0002$ & $4.8 \pm 0.0001$ & $1.45 \pm 0.0001$ & $36.55 \pm 0.0003$ & $12555 \pm 0.0031$ \\
\hline IKSP & $79.81 \pm 0.0005$ & $30.695 \pm 0.0002$ & $9.1 \pm 0.0003$ & $2.95 \pm 0.0001$ & $57.45 \pm 0.0004$ & $10831.5 \pm 0.0014$ \\
\hline OBN & $16.27 \pm 0.0005$ & $34.84 \pm 0.0007$ & $6 \pm 0.0003$ & $1.6 \pm 0.0001$ & $39.7 \pm 0.0003$ & $19797 \pm 0.0018$ \\
\hline OBNH & $11.255 \pm 0.0005$ & $51.78 \pm 0.0009$ & $4.05 \pm 0.0003$ & $2.15 \pm 0.0001$ & $47.35 \pm 0.0001$ & $25276.5 \pm 0.0017$ \\
\hline OBNP & $19.525 \pm 0.0007$ & $37.33 \pm 0.0001$ & $5.75 \pm 0.0001$ & $1.7 \pm 0.0001$ & $49.95 \pm 0.0002$ & $23578 \pm 0.0005$ \\
\hline OBSP & $93.21 \pm 0.0003$ & $39.74 \pm 0.0003$ & $5.6 \pm 0.0015$ & $2.55 \pm 0.0001$ & $56.5 \pm 0.0003$ & $24297 \pm 0.0011$ \\
\hline
\end{tabular}

It was observed that the $\mathrm{NH}$ acid mixture showed good extraction of $\mathrm{Cu}$ for the entire sampled sites. Tayab [27] reported that aqua regia gave higher results because of the solubility of $\mathrm{Cl}^{-}$and $\mathrm{NO}_{3}^{-}$species. Zeng [38] presented results which correlate to those obtained as he verified that NP and SP acid mixtures were more efficient in the recovery of $\mathrm{Cu}$. Sco [39] explained further that $\mathrm{Cu}$ can be leached to achieve $80 \%$ recovery using $\mathrm{H}_{2} \mathrm{SO}_{4}$ which can further be improved to $<90 \%$ by the addition $\mathrm{H}_{2} \mathrm{O}_{2}$.

Very high levels of Fe concentration were recorded in all the samples site. Metals are said to be mainly bond in silicate such as feldspar and Fe-Mn micas by replacing $\mathrm{Ca}^{2+}, \mathrm{Fe}^{2+}$ and other cations in the structure [40.41]. This process liberates Fe ions which can easily be extracted. Nitric acid (N) more often showed the least extraction of Fe. WAS [42] reported that Fe may not be fully recovered from some matrix type (example-grains) using nitric acid. Investigation on digestion of organic matrix with nitric acid found that the digestion did not oxidise the organic matrix completely $[43,44]$. NP has been used for the determination of heavy metals in sediments [37,41]. Higher Fe content was reported by Thalita et al. [35] using nitric- perchloric acid mixture and EPA $3050\left(\mathrm{HCl}+\mathrm{HNO}_{3}+\mathrm{H}_{2} \mathrm{O}_{2}\right)$. However, to overcome safety issues associated with the use of perchloric acid and lack of recovery of $\mathrm{Fe}$ and $\mathrm{Al}$ using nitric acid, WAS [42] stated that the use of aqua regia is preferred for total recovery of $\mathrm{Fe}$ in plants, however when soil is a part of the sample matrix (contaminant), this method does not recover all the Fe. From the result given, $\mathrm{NH}$ predominantly gave a better result for the extraction of Fe in sediments from all the sampled sites.

Due to the relative stable nature of $\mathrm{Cr}$ in sediment [27], the use of SP acid mixture was predominantly the most effective for extraction of $\mathrm{Cr}$ followed by the NP acid mixture. This confirms results from Thalita et al. [35] work where higher contents of $\mathrm{Cr}$ and Fe were recovered when nitric-perchloric acid and EPA 3050 were used in the opening of organic matrices. From the result shown, nitric acid showed the lowest extraction for $\mathrm{Cr}$ for most of the sampled sites. WAS [42] stated that nitric acid cannot be used for total recovery of Cr from plant matrix. Schlieckman et al. [45] reported that the use of chloric acid in combination with $\mathrm{HF}$ and $\mathrm{HNO}_{3}$ in the digestion of dust sample at different temperatures lead to loss of $\mathrm{Cr}$ through the formation of chromyl chloride at higher temperature. 


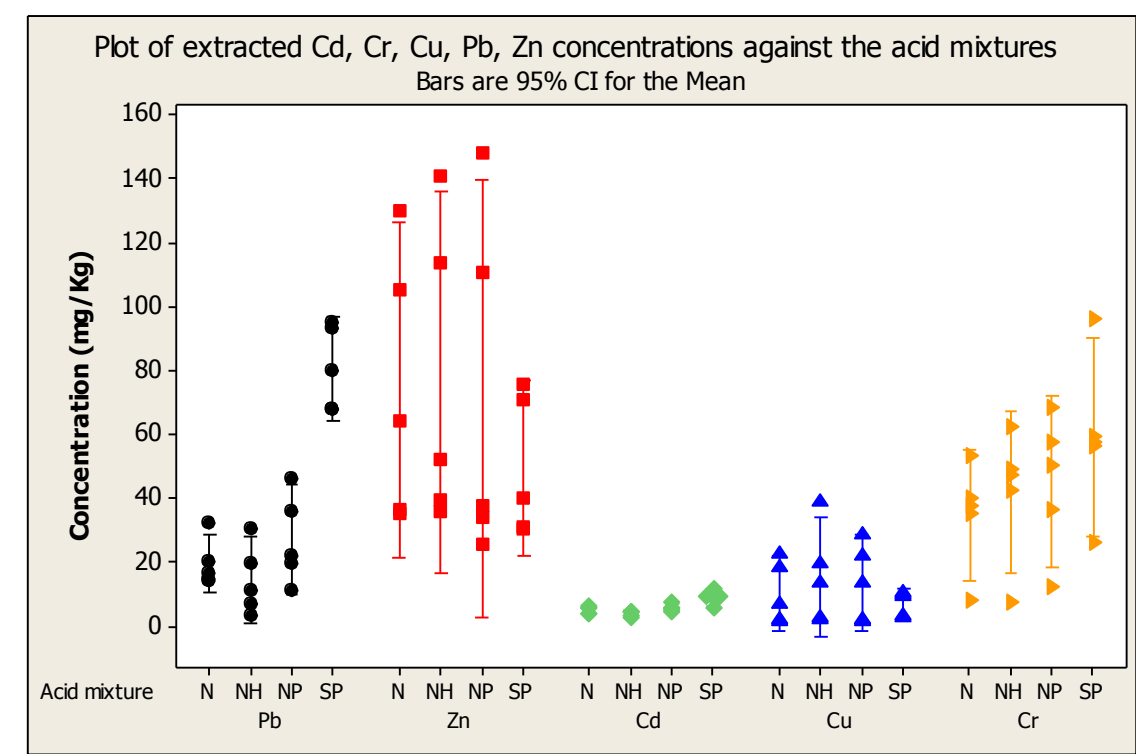

Figure 3: Plot of $\mathrm{Pb}, \mathrm{Zn}, \mathrm{Cd}, \mathrm{Cu}, \mathrm{Cr}$ extracted concentrations against acid mixtures

Table 3 below shows past works on the efficiency of different acid mixtures for determination of metal concentrations in organic samples using standard reference samples. Abreu et al. [46] showed that NH gave the best recoveries for all metals when compared with the use of NP and N. It was clearly shown that nitric acid containing mixtures gave good results for the recovery of $\mathrm{Cu}$ with preference to $\mathrm{NH}$ which gave higher percentage recoveries. Fe recovery was seen to follow the same trend with $\mathrm{NH}$ being the preferred method followed by NP and N. Sulphuric acid containing mixtures gave good results for recoveries of $\mathrm{Cr}$ and $\mathrm{Cd}$, alternatively, $\mathrm{NH}$ was shown to also give good percentage recoveries. For the recoveries of $\mathrm{Zn}$ and $\mathrm{Pb}$, there were variations in results shown below which ranged from NH to NP with optimal results of recovery.

Table 3: Comparison of acid mixtures for recovery of heavy metals in standard materials NH-Aqua regia, N-Nitric acid, NP- Nitric-Perchloric acid, SP- Sulphuric-Hydrogen peroxide, NS-NitricSulphuric acid

\begin{tabular}{|l|l|l|l|l|}
\cline { 2 - 5 } \multicolumn{1}{c|}{} & Abreu et al.[46] & Oyeyiola et al.[47] & Badran et al.[48] & Present Study \\
\hline $\mathrm{Cd}$ & $\mathrm{NH}>\mathrm{NP}=\mathrm{N}$ & $\mathrm{NH}>\mathrm{NS}>\mathrm{NP}>\mathrm{N}$ & $\mathrm{N}>\mathrm{NS}>\mathrm{NP}$ & $\mathbf{S P}>\mathbf{N P}=\mathbf{N H}>\mathbf{N}$ \\
\hline $\mathrm{Cr}$ & $\mathrm{NH}>\mathrm{NP}=\mathrm{N}$ & $\mathrm{NS}>\mathrm{NH}>\mathrm{N}>\mathrm{NP}$ & $\mathrm{N}>\mathrm{NS}>\mathrm{NP}$ & $\mathbf{S P}>\mathbf{N H}>\mathbf{N P}>\mathbf{N}$ \\
\hline $\mathrm{Cu}$ & $\mathrm{NH}>\mathrm{NP}=\mathrm{N}$ & $\mathrm{NH}>\mathrm{NS}>\mathrm{NP}>\mathrm{N}$ & $\mathrm{NS}$ & $\mathbf{N H}>\mathbf{N P}>\mathbf{N}>\mathbf{S P}$ \\
\hline $\mathrm{Pb}$ & $\mathrm{NH}>\mathrm{NP}=\mathrm{N}$ & $\mathrm{NP}>\mathrm{NH}>\mathrm{NS}=\mathrm{N}$ & $\mathrm{NP}>\mathrm{N}>\mathrm{NS}$ & $\mathbf{S P}>\mathbf{N P}>\mathbf{N}>\mathbf{N H}$ \\
\hline $\mathrm{Zn}$ & $\mathrm{NH}>\mathrm{NP}=\mathrm{N}$ & $\mathrm{NH}>\mathrm{NS}>\mathrm{NP}>\mathrm{N}$ & $\mathbf{N P}>\mathbf{N H}>\mathbf{N}>\mathbf{S P}$ \\
\hline $\mathrm{Fe}$ & $\mathrm{NH}>\mathrm{NP}=\mathrm{N}$ & - & $\mathrm{NP}>\mathrm{N}=\mathrm{NS}$ & $\mathbf{N H}>\mathbf{N P}>\mathbf{N}>\mathbf{S P}$ \\
\hline
\end{tabular}

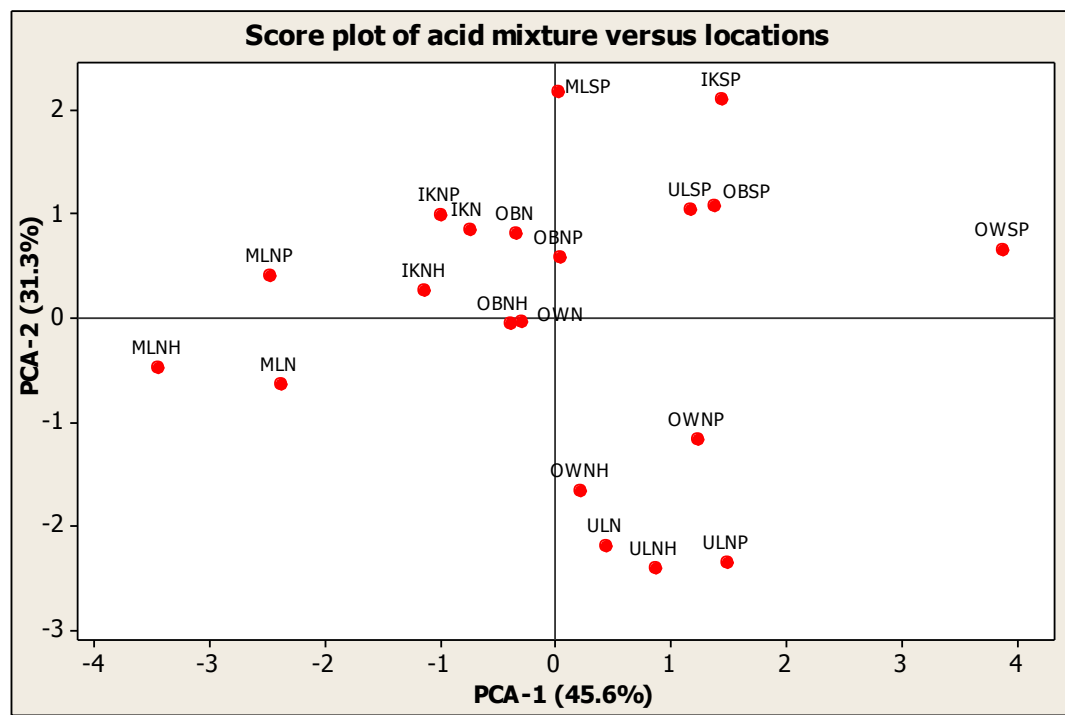

Figure 4: Score Plot of Acid Mixtures versus Locations 
The purpose of Principal Component Analysis (PCA) is to reduce a number of observed variables into a relatively smaller number of components. In this present study, PCA was used with the aim of analyzing the extraction efficiency of acid mixtures within the sediments sampled at different locations on Lagos Lagoon. The score plot of the first two components allows for the characterization of the sampling areas according to acid mixtures concentrations. The three principal components (PCs) explained $77.0 \%$ of the total variance with the values for $\mathrm{PC} 1$, and $\mathrm{PC} 2$ of $45.6 \%$ and $31.3 \%$ respectively. SP acid mixtures exhibited high extraction efficiency of the metals in all the stations, Oko-Baba, Unilag, Mid-lagoon, Ikoyi and Oworonsoki (Fig. 3) and were well differentiated by the higher scores on the first component in the positive part. Sediment samples from Ikoyi and Oko-Baba were separated from other stations in the positive part of the second component suggesting relative good extraction efficiency of acid mixtures $\mathrm{NH}, \mathrm{NP}$ and $\mathrm{N}$ for the regions. Oworonsoki and Unilag sediment samples decomposed by acid mixtures $\mathrm{NH}, \mathrm{NP}$ and $\mathrm{N}$ were clearly separated from other stations in the negative part of the first component suggesting poor/low decomposition (extraction) of metals from sediment of these regions. PC-3 (16.3\%) represented NH and $\mathrm{N}$ acid mixture in the negative part and NP in the positive part due to geochemical characteristics of sediment from Mid-Lagoon.

The variation of the effectiveness of the different acid mixture used at the different sites could be explained using the soil texture. McLean and Bledsof [49] reported that sandy soil did not retain metal effectively, this correlates with the result given where a less oxidizing reagent NH was gave good results for clayed soil of Mid-lagoon and Oworonsoki which stronger oxidizing mixtures of NP and SP gave better results for clay-loamy soils of Unilag, Ikoyi and Oko-baba.

\section{Recommendation}

The SP acid mixture gave the greatest extraction for $\mathrm{Pb}, \mathrm{Cd}$ and $\mathrm{Cr} . \mathrm{H}_{2} \mathrm{O}_{2}$ and $\mathrm{H}_{2} \mathrm{SO}_{4}$ are powerful oxidizers and dehydrating agent. The combination of these two have been said to be the most powerful oxidizing reagent for organic matter in sediment [50] (Polley and Miller, 1955). It was shown that the dissolution of $\mathrm{Pb}, \mathrm{Cd}$ and $\mathrm{Cr}$ using $\mathrm{NH}$ acid mixture and nitric acid method were mostly lower compared to the SP and NP acid mixture. This was also shown by Stoeppler et al. [43] who found that digestion of organic matrix using nitric acid did not completely digest the organic matrix and also Monika [51] who stated that aqua regia digestion does not obtain the true content of species. NP and NH gave good results and to some extent nitric acid for the extraction of $\mathrm{Zn}, \mathrm{Fe}$ and $\mathrm{Cu}$. This is in agreement with Griepink [52] work who reported that addition of strong oxidants $\mathrm{HClO}_{3}$ and $\mathrm{HClO}_{4}$ to $\mathrm{HNO}_{3}$ increases the power of oxidation.

The recoveries of $\mathrm{Zn}, \mathrm{Cu}$ and $\mathrm{Fe}$ in the standard reference material IAEA-158 which ranged from 1954\% were highest using NP for $\mathrm{Zn}$ extraction; $\mathrm{NH}$ for $\mathrm{Fe}$ and $\mathrm{Cu}$ extraction. This indicates that these acid digestion mixtures were not efficient for the extraction of $\mathrm{Zn}, \mathrm{Cu}$ and Fe. Studies have shown that HF has been used for extraction of heavy metals in sediments and soil because it bonds with silicate to form $\mathrm{SiF}_{4}$ enabling total digestion [28,29,53,54], however Atgin et al. [55] pointed out that HF can result in damage of the FAAS apparatus. According to Garcia et al. [54], microwave digestion with HF can decrease the recovery of some chemical element due to the formation of calcium fluoro-aluminates or precipitate calcium. Also the PTFE material used in HF digestion is expensive and when used repeatedly, the seemly stable inert vessel may gradually increase its surface area (cracks) into which part of the digest diffuses losses and memory effect [52].

\section{Conclusion}

The choice of extractants should depend on the aim of the study, type of contaminants, properties of the extractants and experimental conditions. Unfortunately, there was no digestion method which was widely efficient in the extraction of all the metals. This is due to the differing characteristic of each metal in sediment. The advantages of safety, short digestion time, less acid consumption, and high extraction efficiencies should be put into consideration in heavy metal determination. For every metal a possible optimal digestion technique has been recommended. Most of the sediment samples analysed showed that SP acid mixture was efficient for the determination of $\mathrm{Pb}, \mathrm{Cd}$ and $\mathrm{Cr}$. $\mathrm{NP}, \mathrm{NH}$ and also nitric acid mixture are recommended for the qualitative determination of $\mathrm{Zn}, \mathrm{Cu}$ and $\mathrm{Fe}$. However perchloric acid may cause severe explosion if used with large amount of oxidizable matter. It is recommended to use this acid to complete digestion by adding in later stage of digestion.

\section{Reference}

[1]. D.A. Wright and P. Welbourn, Environmental Toxicology (Cambridge University Press, Cambridge: U.K, 2002).

[2]. P.K. Krishnakumar, E. Casillas and U. Varanasi, Effect of Environmental Contaminants on the Health of Mytilusedulis from PugetSound, Washington, USA .1. Cytochemical Measures of Lysosomal Responses in the Digestive Cells Using Automatic ImageAnalysis. Marine Ecology-Progress Series 106, 1994, 249-261.

[3]. C.D. Wren, H.R. McCrimmon, and B.R. Loescher, Examination of Bioaccumulation and Bio magnification of Metals in a Precambrian Shield Lake, Water, Air, and Soil Pollution 19, 1983, 277-291.

[4]. O.O. Aspholm, and K. Hylland, Metallothionein in green sea urchins (Strongylocentrotus droebachiensis) as a biomarker for metal exposure, Marine Environmental Research 46, 1998, 537-540. 
[5]. C.A. Downs, J.E. Fauth and C.M. Woodley, Assessing the health of grass shrimp (Palaeomonete spugio) exposed to natural and anthropogenic stressors: A molecular biomarker system, Marine Biotechnology 3, 2001, 380-397.

[6]. F. Regoli, D. Pellegrini, G.W. Winston, S. Gorbi, S. Giuliani, C. Virno-Lamberti and S. Bomdadre, Application of biomarkers for assessing the biological impact of dredged materials in the Mediterranean: the relationship between antioxidant responses and susceptibility to oxidative stress in the red mullet (Mullus barbatus), Marine Pollution Bulletin 44, 2002, 912-922.

[7]. W.G. Landis, and Y. Ming-Ho, Introduction to Environmental Toxicology: Impacts of Chemicals upon Ecological Systems (CRC Press, Lewis Publishers, Boca Raton, FL, 2003).

[8]. H. Bradl, Heavy Metals in the Environment: Origin, Interaction and Remediation (Elsevier/Academic Press, London, 2005).

[9]. B.A. Zarcinas, B. Cartwright, L.R. Spouncer, Nitric acid digestion and multi-element analysis of plant material by inductively coupled plasma spectrometry, Commun. Soil Sci. Plant Anal. 18, 1987, 131-146.

[10]. L.R. Hossner, Dissolution for Total Elemental Analysis, in D.L. Sparks et al. (Eds), Methods of Soil Analysis, Part 3, Chemical Methods, SSSA Book Series No. 5 (ASA and SSSA ,Madison, WI: U.S.A, 1996) 49-64.

[11]. M. Hoenig, Critical discussion of trace element analysis of plant matrices, Sci. Total Environ. 176, 1995, 85-91.

[12]. R.E. Burau, Lead, in A.L. Page et al. (Eds), Methods of Soil Analysis, Part 2, Chemical and Microbiological Properties, 2nd ed., Agron. Monogr. Vol. 9 (ASA and SSSA, Madison, WI: U.S.A, 1982) 347-366.

[13]. H.M. Reisenauer, Chromium, in A.L. Page et al. (Eds), Methods of Soil Analysis, Part 2,Chemical and Microbiological Properties, 2nd Ed., Agron. Monogr. Vol. 9 (ASA and SSSA, Madison, WI: U.S.A, 1982) 337-346.

[14]. T.T. Gorsuch, Radiochemical investigations on the recovery for analysis of trace elements in organic and biological materials, Analyst 84, 1959, 135-173.

[15]. B.A. Zarcinas, B. Cartwright, Analysis of soil and plant material by inductively coupled plasma-optical emission spectrometry, CSIRO Aust. Div. Soils Tech. Paper No. 45, 1983, 1-36.

[16]. D.E. Baker, and M.C. Amacher, Nickel, Copper, Zinc and Cadmium, in A.L. Page et al. (Eds), Methods of Soil Analysis, Part 2, Chemical and Microbiological Properties, 2nd Ed., Agron.Monogr. Vol. 9 (ASA and SSSA, Madison, WI: U.S.A, 1982 ) 323-336.

[17]. S.P. McGrath and C.H. Cunliffe, A Simplified Method for the Extraction of the Metals Fe, Zn, Cu, Ni, Cd, Pb, Cr, Co and Mn, Soils and Sewage Sludges. J. Sci. Food Agric. 36, 1985, 794-798.

[18]. B.W. Tukura, N.L. Usman and H.B. Mohammed, Aqua regia and ethylenediaminetetracetic acid (EDTA) trace metal levels in agricultural soil, Journal of Environmental Chemistry and Ecotoxicology, Vol. 5(11), 2013, 284-291.

[19]. J. Sastre, A. Sahuquillo, M. Vidal, G. Rauret, Determination of $\mathrm{Cd}, \mathrm{Cu}, \mathrm{Pb}$ and $\mathrm{Zn}$ in environmental samples: microwave assisted total digestion versus aqua regia and nitric acid extraction, Anal. Chem. Acta 462, 2002, 59-72.

[20]. V.D. Zheljazkov and P.R. Warman, Comparison of three digestion methods for the recovery of 17 plant essential nutrients and trace elements from six composts, Compost Sci. Utiliz. 10, 2002, 197-203.

[21]. G.O. Adewuyi, and A.O. Adeleye, Evaluation of polybrominated diphenyl ethers in sediment of Lagos Lagoon, Nigeria, African Journal of Environmental Science and Technology, 7(7), 2013, 686-693.

[22]. D. Adeyemi, C. Anyakora, G. Ukpo, A. Adeleye and G. Darko, Evaluation of the levels of organochlorine pesticides residues in water samples of Lagos lagoon using solid phase extraction, Journal of Environmental Chemistry and Ecotoxicology Vol. 3(6), 2011, 160-166.

[23]. A. Adeleye, D. Adeyemi, J.P. Uyimandu, S. Chigome and C. Anyakora, Evaluation of the level of Polycyclic Aromatic Hydrocarbons in surface and bottom waters of Lagos lagoon, Nigeria, African Journal of Pharmaceutical Sciences and Pharmacy Volume 3, Issue 13(1), 2012, 58-74.

[24]. P.H Quevauviller, M. Lachica, E. Boratora, A. Gomez, G. Rauret, A. Ure, H. Muntau and J. Fresenius, Certified reference material for the quality control of EDTA- and DTPA-extractable trace metal content in calcareous soil (CRM 600), Anal.Chem. 360, 1998, $505-511$.

[25]. J.B. Jones, and V.W. Case, Sampling, handling and analysing plant tissue samples, In: R.L. Westerman, (Ed), soil testing and plant analysis, third ed. Soil science society of America, book series no. 3 (Madison, Wisconsin, 1990) 389-427.

[26]. AOAC, AOAC official method of analysis, $15^{\text {th }}$ Ed. (Association of official analytical chemists, Arlington, Virginia, 1990) 84-85.

[27]. R.M. Tayab, Environmental impact of heavy metal pollution in natural aquatic system, A thesis submitted for the degree of doctor of philosophy, 1991.

[28]. H. Zeng-Yei, C. Zueng-Sang, T. Chen-Chi, T. Chun-Chih, C. Shuang-Fu, L. Chyan-Lan and L. Haw-Tarn, Digestion methods for total heavy metals in sediment and soil, Water, Air, and Soil Pollution 141, 2002, 189-205.

[29]. W. Yawar, C. Naeem, P. Akhter, I. Rehana and M. Saeed, Assessment of three digestion procedure for zinc contents in Pakistani soil by FAAS, J. Saudi chem. Soc. 14, 2010, 125-129.

[30]. S.L. Simpson, S.C. Apte and G.E. Batley, Effect of short term re-suspension events on the oxidation of cadmium, lead and zinc sulphide phases in anoxic estuarine sediments, Environmental science and technology 34, 2000, 4533-4537.

[31]. W. Stumm and P.A Brauner, in G. Skirrow (Ed.) chemical oceanography (academic press NY, 1975) 173-239.

[32]. Y.Y. Zhuang, H.E. Allen and G.M. Fu, Effect of aeration of sediment on cadmium binding. Environmental toxicology and chemistry 13, 1994717-724.

[33]. M.T. Schaanning, K. Hylland, D.O. Eriksen, T.D. Bergan, J.S. Gunnarson and J. Skei, Interaction between eutrophication and contaminants II; Mobilization and bioaccumulation of $\mathrm{Hg}$ and Cd from marine sediment, Marine Pollution Bulletin 33, $1996,71-79$.

[34]. D.M. Di Toro, J.D. Mahony, D.J. Hansen, K.J. Scott, A.R. Carlson and G.T. Ankley, Acid volatile sulphide predicts the acute toxicity of cadmium and nickel in sediments, Environmental science and technology 26, 1992, 96-101.

[35]. FA. Thalita, A.S. Carlos, A.D. Daniela and J.D. Waldete, Influence of digestion methods on the recovery of iron, zinc nickel chromium, cadmium and lead content in eleven organic residues, Rev. bras. Cienc. Solo vol. 38, $2014,0100-0683$.

[36]. K. Nemati, N.K.A Bakar, M.R.B. Abas, E. Sobhanzadeh and K.H. Low, Comparative study of open system digestion and microwave assisted digestion method for metal determination in shrimp sludge compost, J. Hazard Mater 182, 2010, $453-459$.

[37]. J. Morillo, J. Usero and I. Gracia, Heavy metal distribution in marine sediments from the southwest coast of Spain, Chemosphere $55,2004,431-442$.

[38]. H. Zeng-Yei, evaluation of heavy metal contents in nine compost using four digestion methods, Bioresources Technology 95, 2004, 53-59.

[39]. S.Y. Sco, W.S. Choi, M.J. Kim and T. Tran, Leaching of a $\mathrm{Cu}$-Co ore from Congo using sulphuric acid- hydrogen peroxide leachant, J. Min. Metall. Sect. B-Metall. 49, 2013, 1-7.

[40]. C.N. Alpers and D.W. Blowes, Environmental geochemistry of sulphide oxidation, ACS symposium series 550, American chemical society, Washington D.C, 1994.

[41]. W. Shaofeng, J. Yongfeng, W. Shuying, W. Xin, H. Wang, Z. Zhao and B. Liu, Fractionation of heavy metals in shallow marine sediments from Jin Zhou bay, China, Journal of environmental sciences 22(1), 2010, 23-31. 
[42]. Waite analytical services (WAS), All digestion methodology outlines. General outlines 03, 2009.

[43]. M. Stoeppler, K.P. Mueller and F. Backhais, Pretreatment studies with biological and environmental materials, Z. Fres. Anal. Chem. 297, 1979, 107-112.

[44]. S.B. Adeloju, A.M. Bond and M.H. Briggs, Critical evaluation of some wet digestion methods for the stripping voltammetric determination of selenium in biological materials. Anal. Chem. 56(13), 1984, 2397-2401.

[45]. F. Schlieckmann and F. Umland, A new versatile digestion procedure for the multielement determination of heavy metals in air dust samples Z. Fres Anal. Chem. 318, 1984, 495-497.

[46]. M.F. Abreu, R.S. Berton and J.C. Andrade, Comparison of methods to evaluate heavy metals in organic wastes, commun. Soil sci. plant anal. 27(5-8), 1996, 1125-1135.

[47]. A.O. Oyeyiola, K.O. Olayinka, and B.I. Alo, Evaluation of Methods of Extraction and Particle Size on the Determination of Potentially Toxic Metals from Sediments, Journal of Sci. Res. Dev. vol. 13, 2011, $118-128$.

[48]. M. Badran, I. Azizah, R. Morsy and T. Elnimr, Critical evaluation for five digestion methods using ICP-MS, J. Pharm. Sci. innov. 3(1), 2014, 30-34.

[49]. E.J. McLean and B.E. Bledsoe, Behavior of Metals in Soils, Ground water issues.EPA/540/S-92/018, 1992.

[50]. D. Polley and V.L. Miller, Rapid microprocedure for determination of mercury in biological and mineral materials. Anal Chem. 27, $1955,1162-1164$.

[51]. I.K. Monika, Digestion of solid matrices. Part I: Digestion with aqua regia. Report of evaluation study, Horizontal 18, 2005.

[52]. B. Griepink and G. Tolg, Sample digestion for determination of elemental traces in matrices of environmental concern, Pure and Applied Chem. 61(6), 1989, 1139-1146.

[53]. C. Yafa and J.G. Farmer, A comparative study of acid extractable and total digestion methods for determination of inorganic elements in peat material by inductively coupled plasma-optical emission spectrometry, Anal. Chem. Acta. 557, 2006, 296-303.

[54]. C. Garcia-Delgado, V. Calab, E. Eymara, Influence of chemical and mineralogical properties of organic amendments on the selection of an adequate analytical procedure for trace element determination, Talanta 88, 2012, 375-384.

[55]. R.S.W. Atgin, O. El-Agha, A. Zararsiz, A. Kocatas, H. Parlak and G. Tuncel, Investigation of the sediment pollution in Izmir Bay; Trace elements spectrochem. Acta B 55, 2000, 1151-1164. 